\title{
Genitive Case-marked Subject in Modern Mongolian
}

\author{
Dalai Zayabaatar \\ Department of Mongolian Language and linguistics, Faculty of Humanities, The School of Sciences, The National \\ University of Mongolia, Mongolia \\ E-mail: zayabaatar@fpms.meds.gov.mn, zayabaatard@gmail.com \\ Vanchinsuren Dashdavaa \\ Faculty of Humanities, The School of Sciences, The National University of Mongolia, Mongolia \\ E-mail: vdashdavaa@yahoo.com \\ Dagvasumberel Enkhjargal (Corresponding author) \\ Department of European Studies Mongolia, Department of Mongolian Language and linguistics, Faculty of Humanities, \\ The School of Sciences, The National University of Mongolia, Mongolia \\ E-mail: enjee_2011@yahoo.com, enjee2011@num.edu.mn \\ Tsulbaatar Onon \\ Department of Asian Studies, Faculty of Humanities, The School of Sciences, The National University of Mongolia, \\ Mongolia \\ E-mail: tsul_onon@num.edu.mn, tsulbaatar_onon@yahoo.co.jp
}

Doi:10.7575/aiac.alls.v.7n.2p.183

URL: http://dx.doi.org/10.7575/aiac.alls.v.7n.2p.183
Received: 09/12/2015

Accepted: 26/01/2016

The research paper was sponsored by National University of Mongolia.

\begin{abstract}
This paper presents peculiarities of the genitive case marked subject in Modern Mongolian. First, we argue that subordinate clauses with the genitive case-marked subject in Modern Mongolian are CP. Second, we provide an explanation for certain conditions of the genitive subject construction in Modern Mongolian (MM). Third, we attempt to show the genitive case marked subject is semantically restricted and information structurally marked in MM.
\end{abstract}

Keywords: genitive subject, determining suffix, optionality, case alternation

\section{Introduction}

In some languages, subjects are generally marked genitive in certain environments. Dagur (cf.Hale 2002; Martin 1961), Japanese (Bedell 1971; Hiraiwa 2000; Miyagawa 2011), Turkish (Kornfilt and Whitman 2012) Polynesian languages (Herd 2015), Slavic languages (Franks 2005; Robinson 2013).

Dagur (1) [mini au -sen] mery -miny sain.

[1sGen buy-PERF] horse-1sGen good

'The horse I bought is good.' (Hale 2002: 109)

Japanese (2) [watasi-no katta] uma-wa ii.

[I-Gen bought] horse-Top good

'The horse I bought is good.'

Turkish (3) [ben-im al-dığ -1m] at iyi-dir

[I-Gen buy-Factive Nominalizer-1.SG horse good-is

'The horse I bought is good.' (Jaklin Kornfilt.)

Hawaiian (4) Kāna mea i makemake ai i ia wā...

3ps.GEN thing T/A want RESPRN at that time

'The thing that he wanted at that time...' (Hawkins 2000:133) . 


\section{Genitive Case-marked Subject in Modern Mongolian}

\subsection{Previous research}

Phenomena related to the genitive case marked subject of Modern Mongolian have been pointed out and investigated by scholars such as D.Tserenpil and R.Kullmann (2005:392), M.Mizuno (1995), Y.Munkh-Amgalan (2014:253) from a historical perspective.

\subsection{D- licensing or C-licensing?}

Cross-linguistically, there are two main analyses for the genitive case marking on subordinate subject.

(i) The Determiner-licensing Hypothesis

The genitive on the subject is licensed by the D associated with the nominal head (Miyagawa 1993, Ochi 2001; based on Bedell 1972, Saito 1985);

(ii) The Complementizer-licensing Hypothesis

The genitive is licensed by the "subjunctive" morphology of the V-C complex (Hiraiwa 2001), or the whagreement on C (Watanabe 1996), within the clause that contains the genitive subject.

In this paper we focus on the question of how the genitive case marker is assigned in these constructions in Modern Mongolian. Hale (2002:109) claims that relative clause in Dagur ${ }^{1}$ has a structure of aspectual phrase, which is commonly found in prenominal modification. He argues that aspectual phrase is smaller in structure than $\mathrm{CP}$ and it allows nominal head which assigns the genitive case.

(1) a.[[jini au-sen] mery -miny ] sain.

[[2sGEN buy-PERF] horse-2sGEN] good

'The horse you bought is good.'

b. [[mini au-sen] biteg-miny ] adig sain.

[[1sgGEN buy-PERF] book-1sGEN] very good

'The book I bought is very good.' (Hale, 2002:109)

Hale's other reason for positing aspect instead of a full CP is that the verb does not have any agreement. According to Hale, agreement would not occur on the verbal inflection because there is no $\mathrm{C}$ to host the agreement to begin with . Also he argues that aspectual phrase in Dagur allows phi-feature on D to enter into agreement with the subject in the relative clause.

Hale (2002:109) "In the relative clause, the verb itself lacks person/number agreement. If, as my exposition implies, the object relative clause involves agreement, then the putative agreement morphology is postponed and realized (as genitive pronominal agreement) on the head noun".

Against Hale's proposal, we argue that subordinate clauses with the genitive case marked subject are CP, it is the nominalized form of $\mathrm{C}$ that assigns the genitive case marker on the subject and this $\mathrm{C}$ also enters into agreement with the subject. In other words, we argue against Hale's proposal based on the following facts.

First, subordinate verb carries agreement, it would occur on the verbal inflection as shown in (2). In (2.a) the subject "Dulma" of the relative clause is singular and the verb inflection carries agreement (phi-feature). In contrast, (2b) the subject oyutn-uud (students) is plural and the verb has plural inflection.

(2.a) Singular: Dulmaagiin unshsan nom

DulmaaGEN readPAST book.

Int: 'The book that Dulma read.'

(2.b) Plural: $\quad$ Oyutnuudiin unshitsgaasan nom.

StudentsGEN readPL.PAST book

'The book that students read'

Second, Hale's proposal of a relative clause with the genitive case marked subject is D-licensing in Mongolian is complicated to explain the following complement clause with the genitive case marked subject like (3). There is no head noun.

Bi [Dulmaa-giin zahidal bich-sen-iig] medsen

"I know that Dulma wrote a letter"

\footnotetext{
${ }^{1}$ He researches Mongolian under the name of Dagur. Dagur is one of the dialects of Mongolian languages. He proposes "In Dagur, the phi-feature probe merges at D, and presumably it is inherited by N. Hence, what we find in Dagur is Dlicensing as opposed to C-licensing in Turkish" (Hale 2002).
} 
2.3 Determining Suffix in Modern Mongolian ${ }^{2}$

Mongolian is highly agglutinative, and both in morphology and syntax consistently head-final (SOV). Thus, morpheme order in the Mongolian sentences reflects both semantic and syntactic scope. Due to these peculiarities of Mongolian, semantic and syntactic interference between the categories can be observed directly. In Mongolian root and subordinate clauses, verbs exhibit a rich variety of suffixes for tense, some of which are demonstrated below: According to the conventional analysis of Sh.Luvsanvandan (1957) subordinate verb inflection categories in Modern Mongolian are classified in the following ways:

(4) $-\operatorname{san}^{3}$ Gerundive (past simple)

-dag Gerundive (present simple)

-j baigaa Gerundive (present continuous)

- $h$ Gerundive (future) Sh.Luvsanvandan (1957)

Also D.Tserenpil and A.Kullmann (2005) call them Noun Determining Suffixes (NDS) and classify them as shown below.

(5) "san"-Past Tense NDS

“dag” - Indefinite Present NDS

“aa," -Progressive Present NDS

"h" huits", "maar"- Future NDS

In accordance with our study, genitive case-marked construction in Modern Mongolian has the following common properties.

(6) a. Subject bears the genitive case in this context

b. Subordinate verb inflections (suffix) are finite

In light of these properties let's take the following examples in MM.

(7) a. Past: [Uchigdur min-ii av-san] nomuud end baina.

[Yesterday I-GEN buy-PAST] book-PL here are.

"The book that I bought (yesterday) are here"

b. Present: [Unuudur min-ii av-ch baigaa] nomuud end baina.

[Today I-GEN buy-PRESENT] book-PL here are.

Int: "The book that I buy (today) are here"

c. Future: [Margaash min-ii av-h] nomuud end baina.

[Tomorrow I-GEN buy-FUTURE] book-PL here are.

Int: "The book that I buy (tomorrow) are here.

As mentioned in $(7 \mathrm{a}, \mathrm{b}, \mathrm{c}$,$) these subordinate clauses are tensed. This is one of the crucial evidences against D-licencing,$ leading us to adopt the $\mathrm{C}$-licensing approach.

\subsection{Distribution of the Genitive Case-marked Subject in MM}

The aim of this section is to display the nature of the genitive case-marked subject in Modern Mongolian. In accordance with our study, the genitive case-marked subject can be contained in all types of clauses in Modern Mongolian as shown in (8-12)

(8) Subject clause

[Chinii yavsan] chin onojee.

[You-GEN go-PAST] TOP is right.

"It is right that you left"

(9) Predicate Clause

Mongol hel sain sursan ni [ta nariin hicheesniih]

Mongolian language well learn-TOP [you-GEN is the fruit of your efforts]

(That) you learned the Mongolian language well, [is the fruit of your efforts'

\footnotetext{
${ }^{2}$ Recently, this kind of suffixes is called "Determining suffix" in Modern Mongolian "uilt ner-verbal noun" by the scholar (Sh.Luvsanvandan:1957, B.Byambadorj:2006, Y.Munkh-Amgalan:2014), "tsagt ner-noun which shows time" (B.Rinchen:1967, M.Bazarragchaa:1998), "uiliin todotgon holboh nuhtsul-verb determining suffix" (P.Byambasan:1987, Ts.Unurbayan:2004), "neriin todotgon holboh nuhtsul-noun determining suffix" (D.Tserenpil and A.Kullmann:2005), "baidlig ilerhiileh nuhtsul-aspect suffix" (Choi Dong-Guen:2008)

${ }^{3}$ The morpheme "san " has variants like "son" "san"”sen" depending on vowel harmony.
} 
(10) Object Clause

Tuunii irj chadahgui gedgiig bi medej baisan.

[He-GEN come could-not ]COMP I knew.

'I knew that he couldn't come'

(11) Relative Clause

[Bold-iin unsh-san] nom-iig bi avsan.

[Bold-GEN read-PAST] book-ACC I take-PAST

'I took the book that Bold read'

(12) Adverbial Clause

Bi uиniig [tanii helsneer] хийнэ.

I this [youGEN sayPAST.DET.SUFF.instr.] doFUT

I'll do this the way you said it.

(13) Discourse level

[Boldiin huugiin honi sain hariuldagiig] ee! ${ }^{4}$

BoldGEN son GEN sheep well pasture (Exclamation).

Int: "Bold's son pastures his flock of sheep very well”!

\subsection{Genitive Case in Modern Mongolian}

In this section we show that the distributions of the genitive case marker are quite complex and can't be explained within morphosyntax. In Modern Mongolian, genitive case marker indicates various other relationships than possession as shown in (14-16).

(14) a. Dorjiin baishin

Dorj-GEN house

Dorj's house

[DP 5 Dorj's[N' house ]]

(14) b. Batiin nomiin orchuulga

Bat-GEN book-GEN translation

Bat's translation of the book

[DP Bat's [ N'translation [DP of the book]]]

(14) c. Sum hiidiin suirel

Monastery-GEN destruction

The Monastery's destruction [by the soldiers]

[DP the monastry's[N' destruction [by the soldiers]

In (14a), "Dorj" is a possessor, in (14b) "Bat" is an agent, in (14c) "monastery" is a theme. Even though, these determiners have different theta-roles, they are typically used to modify and define nouns. In English, expressions containing determiners like "the" are said to have definite reference in that they refer entity which is assumed to be known to the hearer. In contrast, there are no definite and indefinite articles in Mongolian. Due to this functional parameter we suppose that the genitive case marker "iin" on the word "sum hiid" (monastery) in (14c) probably indicates the definiteness and specificity of its noun and the genitive case-marked word "sum hiidiin" (monastery) functions as a theme.

More specifically, let's take the Mongolian counterpart of English DP “The Monastery's destruction by the soldiers". This DP is not interpreted as DP in Mongolian as it is in English. In other words, this kind of DP is expressed by the relative clause which contains the genitive case marked subject as shown below (15).

(15). [Tserguudiin nuraasan] sum hiid

[soldiers-GEN destroy-PAST] monestary

"The Monastery's destruction by the soldiers"

\footnotetext{
4 The interjection “ээ” in MM expresses exclamation "surprise and astonishment”. Scholars call the interjection “ээ” "sul ug-interjection" (Sh.Luvsanvandan:1957), "dagan chimeh ug-post-positional participle for" (P.Byambasan:1987, Ts.Unurbayan:2004) and "baimjit buteever-modal morpheme" (M.Bazarragchaa:1998).

${ }^{5}$ In work before the mid 1980s structures like (14.a.b.c) would have been analysed as a noun phrase (NP). Since Abney (1987), they have been taken to have a the status of determiner phrase (DP).
} 
The above mentioned example shows us that the word "sum hiid" (monastery) is defined in this clause. Also it displays that the relation between relativization and definiteness has a significant role in analyzing the existence of genitive case marked subject in Mongolian. To make this discussion rather more concrete, let's move to the next section.

\subsection{Information structure and specificity}

Cross-linguistically, information structure can be realized through wide variety of linguistic mechanisms. In English information structure is expressed by pitch, intonation and clefts whereas in Mongolian it can be expressed by anaphora, topic marking affixes, specialized discourse particle and scrambling.

In this section we claim that the genitive case marked subject indicates specificity and topicalization (see Rizzi 1997; Drubig 2003) under certain morpho-syntactic conditions, rather than indicating just a contrast to the subject. In other words, if the information is specific, the subject is genitive case-marked and if the information is generic, the subject is not genitive case- marked.

(14a) Bold-iin huugiin saihan duuldagiig ee.

Bold-GEN son-GEN well sing (exclamation “ee”)

Int: Wow, It is wonderful song that Bold's son sang!

(14b) Ene huugiin saihan duuldagiig ee

This son-GEN well sing

Int: "Wow, It is wonderful song that this son sang!"

(14c) Huugiin saihan duuldagiig ee*

Son-GEN well sing *

Int: Wow, It is wonderful song that the son sang!

As mentioned above (14a) and (14b) are grammatical in that the genitive case marked subject coexists with the pronominal "Bold' and the determiner 'ene"(this) whereas (14c) is ungrammatical because of not containing the determiners like "ene"(“ this" in English).

Also it is observed that it is ungrammatical if nominative case marked subject coexists with exclamation suffix as shown below (15a) whereas it is grammatical nominative case-marked subject does not coexist with exclamation suffix in (15b).

(15a) Huu saihan duuldagiig ee*

$$
\text { Son-NOM well sing* }
$$

(15b) Huu saihan duuldag

\section{Son-NOM well sing-PRESENT SIMPLE}

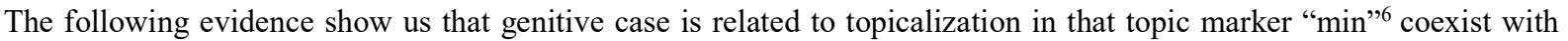
the genitive case marked subject and it doesn't coexists with the accusative and nominative case marked subject.

(16) $\left[\right.$ Aav $^{*} / \mathrm{iin} / \mathrm{iig} / *$ min hiisen $]$ emeeliig chi harav $u$ u?

[Aav-NOM*/-GEN/ACC* -TOP make-PAST] emeel-ACC you see-PAST-QUESt

"Did you see the saddle that my father made"

Also evidence in support of this claim comes from the following sentences.

(17a) [Udur bur nuguu huuhdiin uilah] chimee

Everyday child-GEN cry-h noise

The noise which (certain) child cries everyday

(17b) [Udur bur nuguu huuhed uilah] chimee

Everyday child -NOM cry-h noise

The noise which (uncertain) a child cries everyday

(17c) ) [Udur bur nuguu huuhdiig uilah] chimee*

Everyday child -ACC cry-h noise

The noise which (certain) child cries everyday

Note that the choice of the genitive, accusative and nominative case-marked subjects leads to specific and nonspecific information respectively as shown in (17a.b.c). In the light of this (17.a.b.c), let's look at the following subjects which are substituted by pronoun .

(18a) [Udur bur tuunii uilah] chimee

Every day she-GEN cry-h noise

The noise which (certain) he cries everyday

${ }^{6} \mathrm{D}$. Tserenpil (2005) considers "min" in MM as a Case-bound particles which expresses topic meaning. 
(18b) [Udur bur ter uilah] chimee* $^{*}$

Everyday child -NOM cry-h noise

The noise which (uncertain) he cries everyday

(18c) [Udur bur tuuniig uilah] chimee*

Every day he -ACC cry-h noise

The noise which (certain) child cries everyday

As shown in (18a.b.c) only (18a) is grammatical whereas (18.b) and (18.c) are unavailable because of the replaced pronoun "ter" (he/she). It means that pronoun is always assumed to be known to the addressees as illustrated below:

\section{(19) Definiteness Scale}

Personal pronoun $>$ proper pronoun $>$ definite NP>indefinite NP (Klaus von Heusinger\& Jacklin Kornfilt 2005).

Having looked at these evidences that a genitive case marked subject refers to definiteness and specificity in Modern Mongolian, we now turn to look at a rather different kind of operation.

\section{Optionality in Case marking in Relative clauses}

\subsection{Japanese}

According to the previous literature Miyagawa (1989), in the Japanese relative clauses the genitive subject is possible, but the nominative case may occur instead. But in Mongolian only the genitive case is allowed.

a.山田が/の買った]本

Yamada-GEN/NOM buy-PAST book

"The book that Yamada bought"

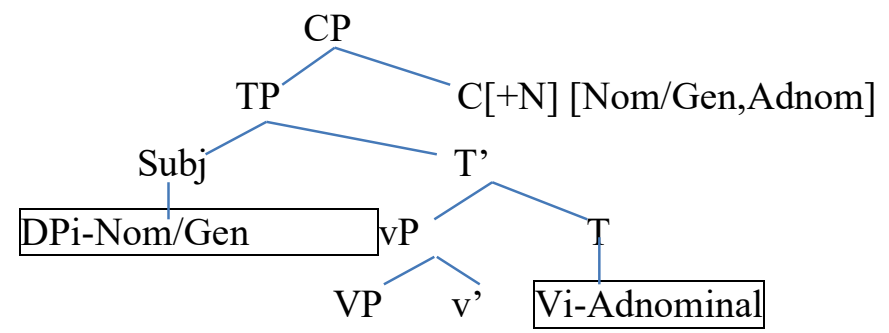

(Banno:2013)

b. Mongolian:

[Dulmaagiin hiisen] hool

Dulmaa-NOM*/GEN do-PAST] food

"The food that Dulma cooked"

In above mentioned environments, the subject that is usually marked by the nominative case marking can appear in the genitive case marking. In contrast, in the Mongolian relative clause, there is no optionality and only the genitive case marking is possible as shown in (b).

3.2 Case Alternation in Mongolian Complement Clauses

The case marking optionality within the complement clauses in Modern Mongolian is reversal of the optionality in Japanese complement clauses. In Japanese complement clauses allow only nominative subject whereas in Mongolian complement clauses triple case alternation (nominative, accusative and genitive) is possible.

\section{(12) Japanese}

[CP anata-ga /*no uti-de tabemono-o tukuru to] kiita.

you NOM/*GEN home-at food-ACC cook C] heard.

"(I) heard that you will cook food at home"

\section{(13) Mongolian}

a. [Dulma hool hii-sen-iig] bi medsen

[Dulma-NOM food cook-ACC] I know

'I know that Dulma cooked at home'

b. [Dulma-giin hool hii-sen-iig] bi medsen

[Dulma-GEN food cook-ACC] I know 
'I know that Dulma cooked at home'

c. [Dulma-g hool hii-sen-iig] bi medsen

[Dulma-ACC food cook-AND-ACC] I know

'I know that Dulma cooked food at home'

Except for the difference on the subject case markers, the patterns of verbal predicate within the complement clauses are identical as shown in (12a.b.c). This evidence leads us to conclude that subordinate clauses with the genitive case marked subject is C-licensing in Modern Mongolian. For our present purposes, however, nominative case marked subject as shown in (12) accusative case marked subject as illustrated in (12.c) are not immediately relevant, since they can be combined with ECM, DOM.

\subsection{Distribution of Nominative, Genitive and Accusative Case-marked Subject}

D.Tserenpil and R.Kullmann, (2005:392), B. Purev-Ochir (2001:334) M.Mizuno (1995) research the distributions of case alternation. M.Mizuno (1995) formulates the case alternation in MM as shown in table.

\section{1) $\mathbf{N}>\mathbf{G}>\mathbf{A}$}

\begin{tabular}{|l|l|}
\hline $\begin{array}{l}\text { a.[Galt irsen ] gej unen uu? } \\
\text { [Galt-NOM come-PAST] COMP true ? }\end{array}$ & Is it true that Galt come? \\
\hline $\begin{array}{l}\text { b.[Galt -iin irsen] gej unen uu? } \\
\text { [Galt-GEN come-PAST ] COMP true? }\end{array}$ & \\
\hline $\begin{array}{l}\text { c.[Galt-iig irsen ] gej unen uu? } \\
\text { [Galt-ACC come-PAST ] COMP true? }\end{array}$ & \\
\hline
\end{tabular}

2) $\mathbf{N}>\mathbf{A}>\mathbf{G}$

a.[Dorj ene nom avsan iig ] bi saya medlee

[Dorj-NOM this book-ACC] I just found

b.[Dorjiig ene nom avsan iig ] bi saya medlee

[Dorj-ACC this book-ACC] I just found

c.[Dorjiin ene nom avsan iig ] bi saya medlee

[Dorj-GEN this book-ACC] I just found

3) $\mathbf{G}>\mathbf{N}>\mathbf{A}$

a.Minii irsen mashin iig chi harav uu?

I-GEN come-PAST car-ACC you see-PAST?

b. Bi irsen mashin iig chi harav uu?

I-NOMcome-PAST car-ACC you see-PAST?

c.Namaig irsen mashin iig chi harav uu?

I-ACC come-PAST car-ACC you see-PAST?

\section{4) $\mathbf{G}>\mathbf{A}>\mathbf{N}$}

a.[Chinii irseniig] bi saya medlee

[You-GEN come-ACC] I just find-PAST

b. [Chamaig irseniig] bi saya medlee

[You-ACC come-ACC] I just find-PAST

c.[Chi irseniig] bi saya medlee

[You-NOM come-ACC] I just find-PAST

5) $\mathbf{A}>\mathbf{N}>\mathbf{G}$

a.[Namaig irtel] chi huleej bai

[I-ACC come-until] you wait keep.

b.[Bi irtel] chi huleej bai

[I-NOM come-until] you wait keep

c. [Minii irtel] chi huleej bai

[I-GEN come-until] you wait keep
I've just found out that Dorj bought this book.

Have you seen the car I came with?

I've just found out that you came.

Keep waiting, until I come! 


\section{6) $\mathrm{A}>\mathrm{G}>\mathrm{N}$}

\begin{tabular}{|c|c|}
\hline $\begin{array}{l}\text { a.[Chamaig surguuli deer irseniig] bi saya medlee } \\
\text { [You-ACC school at come] I just found }\end{array}$ & I've just found out that you came to school. \\
\hline b. [Chinii surguuli deer irseniig] bi saya medlee & \\
\hline [You-GEN school at come] I just found & \\
\hline $\begin{array}{l}\text { c. [Chi-NOM surguuli deer irseniig] bi saya medlee } \\
\text { [You-ACC school at come] I just found }\end{array}$ & \\
\hline
\end{tabular}

In addition to this terminology, we can explain the distributions of case alternation in detail from a discourse perspective.

\section{1. $\mathbf{N}>\mathbf{G}>\mathbf{A}$}

As shown in table (1), this nominative case-marked subject indicates the meaning that "Galt is highlighted while in (b) the genitive case marked subject displays that the action " come or not" is very important for the speaker. Also it represents familiar information and highlights overall sentence.

However, there is not any obvious difference of meaning between the subordinate clause with the genitive case-marked subject and the subordinate clause with the accusative case-marked subject, Mongolian native speakers can tell easily the differences from a discourse perspective. As we seen in (c), the sentence is ungrammatical.

Based on this observation, we propose the following terminology: $\mathbf{N}=\mathbf{G}>\mathbf{A}$

\section{2. $\mathbf{N}>\mathbf{A}>\mathbf{G}$}

As illustrated in table (2.a) the nominative case-marked subject "Dorj" is highlighted whereas as shown in (2.b) the object "book" is highlighted from a semantic perspective. The sentence in table (2.c) indicates that overall activity is highlighted by the speaker. Thus we propose formulation $\mathrm{N}=\mathrm{A}=\mathrm{G}$ instead of preference ordering by Masanori (1995).

3.G $>\mathbf{N}>\mathbf{A}$

As shown in table (3.a) the relative clause with the genitive case-marked subject "min-ii" is grammatical whereas the relative clause with the accusative case-marked subject in (3b) and the relative clause with the nominative case marked subject in (3c) are ungrammatical. Thus we suggest the following plausible formulation $\mathrm{G}>\mathrm{N}>\mathrm{A}$ instead of $\mathrm{G}>\mathrm{N}=\mathrm{A}$.

\section{4. $\mathbf{G}>\mathbf{A}>\mathbf{N}$}

In terms of the clause in (4.a), overall activity of the agent is highlighted. The accusative-case-marked subject " chamaig" (you-ACC) in (4b) is highlighted by the speaker. The sentence (4c) is not grammatical since it contains nominative case-marked subject "chi"(you). Thus, instead of $\mathbf{G}>\mathbf{A}>\mathbf{N}$, we prefer $\mathbf{G}=\mathbf{A}>\mathbf{N}$.

\section{5. $\mathbf{A}>\mathbf{N}>\mathbf{G}$}

Table (5) shows that only adverbial clause with the accusative case-marked subject is grammatical. Consequently, the expression $\mathbf{A}>\mathbf{N}=\mathbf{G}$ is convenient in terms of distributions.

\section{6. $\mathbf{A}>\mathbf{G}>\mathbf{N}$}

As explained in (1-4), only the accusative case-marked subject in (6a) is highlighted whereas overall complement clause with the genitive case-marked subject in (6b) is highlighted by the speaker. The complement clause (6c) is ungrammatical. So we proposed $\mathbf{A}=\mathbf{G}>\mathbf{N}$.

\section{Conclusion}

To sum up, first, we have maintained in this paper that clauses with genitive case-marked subject in Modern Mongolian are C-licensing. Also we show that relative clauses allow only genitive case -marking in Modern Mongolian whereas nominative and genitive case conversion is possible in Japanese relative clauses.

Second, we attempt to explain distributions of all types of clauses with genitive case-marked subject in Modern Mongolian. And we show that genitive case-marked subject and verb with a determining suffix which has verbal properties coexist in Modern Mongolian.

Finally, we provide an account for the distributions of the genitive case marked subject in connection to information structure and topicalization. In accordance with our study, the fact that genitive case marked subject of finite clause in Modern Mongolian correlates with specific reading of the overall clause. Moreover, adopting the proposal by Mizuno Masanori (1995), we provide more explanations in reference to information structure ( Lopez 2009, Bruel 2005).

\section{References}

In English and in Japanese

Banno.O (2013). On Ga/No Conversion: A diachronic Corpus-based Study. 第4回コーパ ス日本語学ワークショッ プ予稿集, 国立国語研究所, 177-186. 
Blake. B.J. (2004) Case. Cambridge University Press

Breul, C. (2005). Focus Structure in Generative Grammar. Amsterdam/Philadelphia: John Benjamins

Choi, D.G. (2008). Solongos ba Mongol helnii ugsiig aimaglah tuhai (Lexicology of Korean and Mongolian) Republic of Korea. Seoul. Journal of the Korean Association for Mongolian Studies, 8, 125-144

Aygen, G. (2007). Syntax and Semantics of Genitive Subject-Case in Turkic. California Linguistic Notes. Volume XXXII No. 2 Spring

Smith, H. (2006). Restrictiveness in case theory. Cambridge

Hiraiwa. K. (2000). On nominative-genitive conversion, in MIT working papers in linguistics 39: A few from Building E39. Cambridge, Mass. 66-125.

Herd, J. (2004). Genitive relative constructions in Polynesian. Proceedings of the 2004 annual conference of the Canadian linguistic Association

Luiz, L. (2009). Derivational Syntax for Information Structure. Oxford University Press

Miyagawa, S. (2008). Genitive in Altaic, Proceedings of the Workshop on Altaic Formal Linguistics4, MIT Working papers in Linguistics

Miyagawa, S. (2011). Genitive Subjects in Altaic and Specification of Phase. Lingua, 121, 1265-1282.

Miyagawa, S. (2012) Case, Argument Structure, and Word Order, Leading Linguistics Series, Routledge.

Mizuno, M. (1995). Preference Ordering of Subject Form in Modern Mongolian, Tokyo University Linguistic Papers, March

Tserenpil, D., Kullman, A. (2005). Mongolian Grammar. Ulaanbaatar

Watanabe, A. (1996). "A cross-linguistic perspective on Japanese nominative-genitive conversion and its implecations for Japanese syntax” In Current topics in English and Japanese. ed. Nakamura.M, Hitsuzi Shobo. 341-369.

\section{In Mongolian}

Bazarragchaa, M. (1998). Hariyalahin tiin yalgalin utgig angilah ni (Classification of the genitive case), Ulaanbaatar, Gurvan Erdene University Bulletin, 2, 7-49

Bazarragchaa, M. (1999). Mongol helnii uiliin tiin yalgal (Verb Cases of Mongolian) Ulaanbaatar

Byambadorj, B. (2006). Orchin tsagiin mongol helnii helber sudlal (Morphology of Modern Mongolian) Ulaanbaatar

Byambasan, P. (1987). Uil ugiin todotgon holboh nuhtsul (Verbal determining suffix) Ulaanbaatar, Institute of Linguistic, Science Academy of Mongolia Bulletin Volume 4. 86-108

Luvsanvandan, Sh. (1957). Orchin tsagiin mongol hel (Modern Mongolian) Ulaanbaatar

Mongol hel shinjleliin tailbar toli bichig (Encyclopedic dictionary of Mongolian linguistics) 2014: Ulaanbaatar,

Munkh-Amgalan, Y. (2014). Orchin tsagiin mongol helnii helber sudlal (Morphology of Modern Mongolian) Ulaanbaatar

Orchin tsagiin mongol hel (Modern Mongolian) 2004:Ulaanbaatar

Purev-Ochir, B. (2001). Orchin tsagiin mongol helnii ögüülberzüi (Syntax of modern Mongolian) Ulaanbaatar

Rinchen, B. (1967). Mongol bichgiin helnii zui (Mongolian Grammar) Ulaanbaatar

Unurbayan. T. (2004). Orchin tsagiin mongol helnii helber sudlal (Morphology of Modern Mongolian) Ulaanbaatar 